Citation: J. Ágoston, A. Almási, K. Salánki, L. Palkovics (2021) Sternbergia lutea, a new host of Narcissus late season yellows virus. Phytopathologia Mediterranea 60(3): 403-407. doi: 10.36253/phyto-12709

Accepted: July 13, 2021

Published: November 15, 2021

Copyright: @2021 J. Ágoston, A. Almási, K. Salánki, L. Palkovics. This is an open access, peer-reviewed article published by Firenze University Press (http://www.fupress.com/pm) and distributed under the terms of the Creative Commons Attribution License, which permits unrestricted use, distribution, and reproduction in any medium, provided the original author and source are credited.

Data Availability Statement: All relevant data are within the paper and its Supporting Information files.

Competing Interests: The Author(s) declare(s) no conflict of interest.

Editor: Assunta Bertaccini, Alma Mater Studiorum, University of Bologna, Italy.

\section{Short Notes \\ Sternbergia lutea, a new host of Narcissus late season yellows virus}

\author{
János ÁGOSTON ${ }^{1,2}$, Asztéria ALMÁSI ${ }^{3}$, Katalin SALÁNKI³ ${ }^{3}$ LÁszló \\ PALKOVICS ${ }^{1,4, *}$ \\ ${ }^{1}$ Hungarian University of Agriculture and Life Sciences, Institute of Plant Protection, \\ Department of Plant Pathology, Ménesi Road 44., H-1118 Budapest, Hungary \\ ${ }^{2}$ Department of Agriculture, Faculty of Horticulture and Rural Development, John Von \\ Neumann University, Mészöly Gyula Square 1-3., H-6000 Kecskemét, Hungary \\ ${ }^{3}$ Eötvös Lóránd Research Network, Centre for Agricultural Research, Plant Protection \\ Institute, Herman Ottó Street 15., H-1022 Budapest, Hungary \\ ${ }^{4}$ Széchenyi István University, Faculty of Agriculture and Food Sciences, Department of \\ Plant Sciences, Vár square 2., H-9200 Mosonmagyaróvár, Hungary \\ ${ }^{*}$ Corresponding author. E-mail: palkovics.laszlo.amand@sze.hu
}

\begin{abstract}
Summary. In autumn 2017, autumn daffodil plants with yellow-green stripes on the leaves were observed at a botanical garden in Budapest, Hungary. Indicator plants were inoculated, but symptoms did not develop. RT-PCR tests of the indicator plants were also negative for the viruses. Potyvirus specific ACP-ELISA and RT-PCR were carried out on the symptomatic $S$. lutea leaf samples. RT-PCR with universal potyvirus primers resulted in one, approx. 1700 base pair PCR product. Phylogenetic analysis of the nucleotide sequence of the coat protein demonstrated $98.78-99.51 \%$ identity with three Japanese isolates of Narcissus late season yellows virus. While unidentified potyvirus infection of autumn daffodil has been previously reported, sequence data have not been published. Therefore, this is the first report of Sternbergia lutea as a host of Narcissus late season yellows virus.
\end{abstract}

Keywords. Potyvirus, Hungary, daffodil.

\title{
INTRODUCTION
}

Sternbergia lutea (autumn daffodil, Amaryllidaceae) is an ornamental plant in the family (Bryan, 2002, 2005), which is grown for golden yellow flowers it produces in autumn, when other flowers are scarce. Leaves also appear in autumn (Bryan, 2002, 2005) and remain till the end of the following, unless damaged by hard frosts. Dry summers and full sun are necessary for flowering (Bryan, 2002, 2005).

In the autumn of 2017, bulbous plants in the botanical garden of the Hungarian University of Agriculture and Life Sciences, Buda Campus (Budapest, Hungary) were surveyed for possible virus infections. Several Sternbergia lutea plants showed heavy, 2-5 $\mathrm{mm}$ wide, yellow to yellow-green stripe 


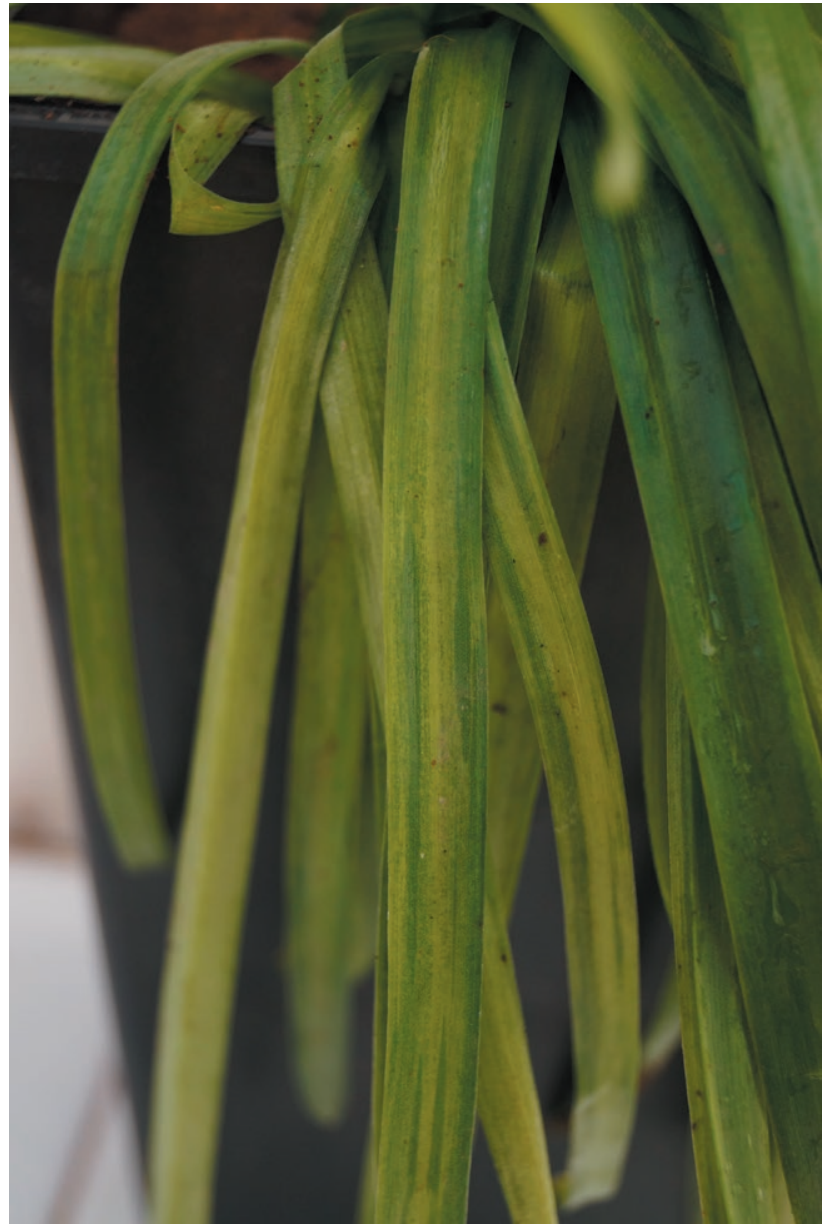

Figure 1. Symptoms of possible virus infection on leaves of Sternbergia lutea.

mosaic symptoms parallel to the veins on the entire length of leaves, that were indicative of possible virus infection (Figure 1).

Flowering of these plants has not been observed since the first year of planting in 2006, probably because the plants were planted below shadowing trees, but virus infections may have had also prevented flowering. There has been only one report of presumed potyvirus infection of autumn daffodil (Pleše, 1993) but the virus species was not identified, nor were sequence data published.

\section{MATERIALS AND METHODS}

\section{Plant samples}

A symptomatic clump of $S$. lutea plants were dug up in the autumn of 2017 from the Buda Campus botani- cal garden. Plants were potted and kept in an insect-free greenhouse in the first growing cycle, and were later planted in open-field conditions.

\section{ELISA tests}

In January of 2018 leaf samples were collected from the potted plants. ACP-ELISA tests were carried out by Agdia, based on the MAb PTY1 antibody (RRID:AB_2819158) (Jordan and Hammond, 1991). All tests were carried out in duplicate, according to the manufacturer's protocol. For each sample, $200 \mathrm{mg}$ of leaf tissue was ground in $20 \mathrm{~mL}$ (1: $100 \mathrm{~m}: \mathrm{v})$ of indirect sample extraction buffer. Aliquots of $100 \mu \mathrm{L}$ of the diluted sample were added to each test plate well, and then incubated at room temperature for $1 \mathrm{~h}$. The wells were then emptied and washed seven times with phosphate buffered saline Tween (PBST). The monoclonal detection antibody, in mouse against potyvirus coat protein (Clone PTY1), was diluted 1: 100 (v:v) in conjugate buffer (ECI buffer), and $100 \mu \mathrm{L}$ was added and incubated overnight at $4^{\circ} \mathrm{C}$. Plates were then washed eight times with PBST. The enzyme conjugate polyclonal rabbit antibody against mouse IgG was diluted with ECI buffer to 1: 100 (v:v), and $100 \mu \mathrm{L}$ was added to each plate well and incubated at room temperature. The plates were then washed eight times with PBST. Paranitrophenyl phosphate (pNPP) was added to PNP buffer at $1 \mathrm{mg} \mathrm{mL}^{-1}$, and $100 \mu \mathrm{L}$ was added to each plate well. Absorbance values were measured at $405 \mathrm{~nm}$ wavelength $30 \mathrm{~min}$ after addition of pNPP, using a Labsystem Multiskan MS ELISA reader. Positive controls were provided by the manufacturer, and negative controls were prepared from Chenopodium amaranticolor seedlings grown in an insect-free greenhouse. A sample was considered positive if the sample absorbance was at least three times greater than that of the negative control.

\section{Herbaceous indexing}

Chenopodium foetidum, Nicotiana benthamiana and $N$. tabacum 'Xanthi' plants were inoculated mechanically (0,02 M Sörensen's phosphate buffer, celite) with the sap of the same leaf used for ACP-ELISA testing. Plants were grown in an insect-free greenhouse, and symptom development was assessed during a 5 -week post inoculation period.

\section{RNA extraction, RT-PCR, and cloning}

Total RNA was extracted from the same symptomatic leaf of Sternbergia lutea collected for ELISA and 
inoculation tests, and from leaves of the inoculated herbaceous indexing plants, 5 weeks post inoculation. The protocol of White and Kaper (1989) was used. RTPCR was carried out with universal potyvirus primers poty7941 and poly $\mathrm{T}_{2}$ (Salamon and Palkovics, 2005). The primers amplified the $\mathrm{C}$ terminal part of the RNAdependent RNA polymerase (RdRp, NIb) including the highly conserved GNNSGQP motif, the complete coat protein (CP) sequence, and the complete 3' untranslated region (UTR) to the first few bases of the polyA tail. PCR products were separated in $1 \%(\mathrm{w} / \mathrm{v})$ agarose gel electrophoresis in $1 \times$ Tris-Borate-EDTA (TBE) buffer. The gel was stained with ethidium bromide and the products were visualized and photographed under UV light. Amplicons of the expected size (approx. $1700 \mathrm{nt}$ ) were purified using the High Pure PCR Product Purification Kit (Roche). The PCR product was cloned into pGEM ${ }^{\circ}$-T Easy vector (Promega), following manufacturer's instructions. PstI digestion of the purified PCR product was carried out to verify its ability to be digested for further cloning.

Additionally, RT-PCR was carried out for Cucumber mosaic virus (CMV), using the protocol described by Nemes and Salánki (2020). CMV is known to have a wide host range and also infects monocotyledonous bulbous ornamental plants (van Rijn et al., 1995; de Best et al., 2000). The sample was also tested for Narcissus latent virus (NLV) and Narcissus mosaic virus (NMV), using multiplex RT-PCR (He et al., 2019), as these viruses have been reported to infect daffodils in Hungary (Ágoston et al., 2020).

\section{Koch's postulates}

To fulfill Koch's postulates, an asymptomatic S. lutea plant was mechanically inoculated with sap from the symptomatic S. lutea plant in April 2019, as described above. Molecular identification for virus from the inoculated plant was performed as described above.

\section{Sequencing, and sequence analyses}

The cloned fragment was sequenced in both directions using M13 forward and reverse primers in an ABI Prism automatic sequencer (BaseClear B.V.). Nucleotide sequence identities were determined by BLAST analyses. Further phylogenetic analyses were carried out with the MEGA-X program (Kumar et al., 2018). ClustalW (Larkin et al., 2007) multiple sequence alignment was carried out (gap opening penalty 15.00, gap extension penalty 6.66 for pairwise and multiple alignment, transition weight 0.5 , ClustalW weight matrix, no negative matrix was used) on the complete coat protein (CP) sequences.

A Maximum Likelihood phylogenetic tree (Felsenstein, 1981) was constructed with the Hasegawa-KishinoYano model (Hasegawa et al., 1985) with gamma distribution and invariant sites. This substitution model had the lowest Bayesian Information Criterion (5682.807). To test the phylogeny the tree was bootstrapped 1,000 times (Felsenstein, 1985).

\section{RESULTS AND DISCUSSION}

Mechanical inoculation of herbaceous test plants C. foetidum, N. benthamiana and N. tabacum 'Xanthi' with plant sap of symptomatic Sternbergia leaf resulted in plants remaining symptomless throughout the 5 week observation period. RT-PCR tests were also negative. Most potyviruses with monocotyledonous hosts do not infect dicotyledonous plants (Mowat et al., 1988). In the ACP-ELISA tests, the absorbances were 0.947 and 0.953 , while respective negative controls were 0.034 and 0.047 , indicating the presence of Potyvirus infections. Universal potyvirus group specific RT-PCR resulted in an approx. 1700 nt product. RT-PCR tests for CMV, NLV and NMV were negative.

The mechanically inoculated S. lutea plant showed the same symptoms as the original infected plant (Figure 1 ), but the symptoms appeared only in the next growing season, in October of 2019, approx. 7 months after inoculation. Flowering of the inoculated $S$. lutea was not observed, possibly because the bulb was not of flowering size. RT-PCR of the inoculated plant also resulted in the expected PCR products size of approx. $1700 \mathrm{nt}$.

The nucleotide sequence of the cloned PCR product from the original symptomatic S. lutea plant, coding the complete coat protein region, included a unique Pst $\mathrm{I}$ recognition site (GenBank accession No. MK783944). Pst I digestion of the original PCR product and from the inoculated plant resulted the two predicted fragments. This indicated identification of a single Potyvirus in the infected leaf tissues and in the inoculated plant, confirming the virus as the agent causing the observed disease (fulfilment of Koch's postulates). BLAST analysis of the CP nucleotide sequence revealed greatest identity with Hungarian (MK132194 - 98.64\%, MK132193 98.34\%), Australian (MH886515 - 96.47\%), and Japanese (LC158450 - 99.51\%, LC158451 - 99.39\%, LC158467 - 98.78\%) isolates of Narcissus late season yellows virus (NLSYV) deposited in GenBank.

Further phylogenetic analyses were carried out with the following NLSYV GenBank sequences: 


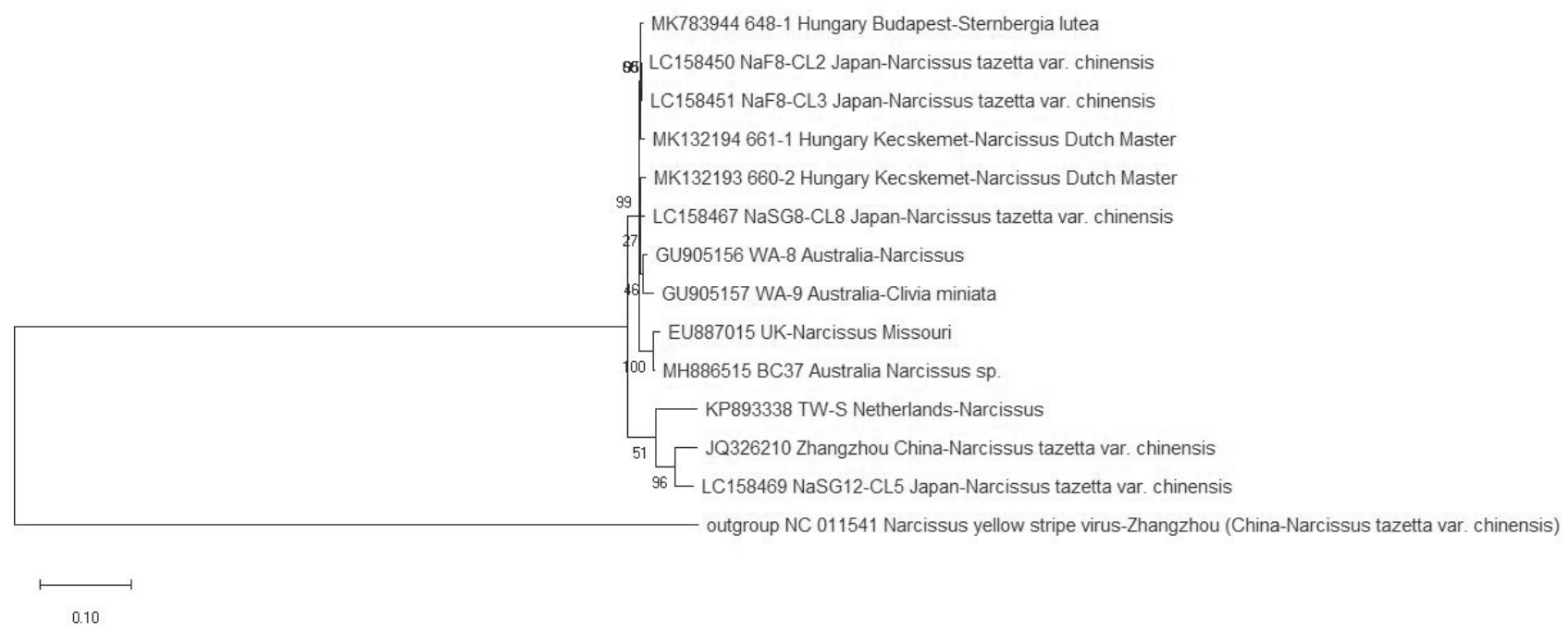

Figure 2. Phylogenetic tree of Narcissus late season yellows virus nucleotide sequences of the complete coat protein regions.

EU887015, GU905156, GU905157, JQ326210, KP893338, LC158450, LC158451, LC158467, LC158469, MH886515, MK132193, MK132194, MK783944, and for the outgroup sequence of Narcissus yellow stripe virus (GenBak accession number NC_011541) was used. After production of the first ClustalW alignment (Larkin et al., 2007) on the complete CP sequence tested, DNA evolutionary models were applied, and a Maximum Likelihood phylogenetic tree (Felsenstein, 1981) was constructed (Figure 2).

The phylogenetic tree divided the virus isolates in two clades. One clade consisted of three NLSYV strains from Narcissus sp. from the Netherlands, China and Japan, while the other was composed of ten strains, eight collected from Narcissus and two isolated from different plant species, i.e., Clivia miniata from Australia and the Hungarian strain from S. lutea. With the exception of the GenBank accession GU905157 from C. miniata from Australia, the other NLSYV strains present in the analysis derived from Narcissus varieties. This is because daffodil is the main host of NLSYV, although not all the cultivars were reported to be susceptible to this virus (Mowat et al., 1988).

Only one presumable Potyvirus infection has been previously reported from $S$. lutea, where electron microscopy of the leaf tissue showed cylindrical inclusions and filamentous particles in the cytoplasm (Pleše, 1993), but the virus was not identified to species level. The present report confirms the presence of a potyvirus in S. lutea, which has been identified as Narcissus late season yellows virus.

\section{ACKNOWLEDGEMENTS}

This research was supported by the project EFOP3.6.1-16-2016-00006 "The development and enhancement of the research potential at John von Neumann University". The study was funded by the Hungarian Government and co-financed by the European Social Fund, and by the Ministry for Innovation and Technology within the framework of the Thematic Excellence Programme 2020 - Institutional Excellence Subprogram (TKP2020IKA-12) for research on plant breeding and plant protection.

\section{LITERATURE CITED}

Ágoston J., Almási A., Nemes K., Salánki K., Palkovics L., 2020. First report of hippeastrum mosaic virus, narcissus late season yellows virus, narcissus latent virus and narcissus mosaic virus in daffodils from Hungary. Journal of Plant Pathology 102: 1275-1276. DOI: 10.1007/s42161-020-00556-9.

Bryan J.E., 2002. Bulbs. Portland, Or, Timber Press, 524 pp.

Bryan J.E., 2005. Timber Press Pocket Guide to Bulbs. Portland, Or, Timber Press, 227 pp.

de Best A.L.I.C., Zwart M.J., van Aartrijk J., van den Ende J.E., Peeters J.M.M., 2000. Ziekten en afwijkingen bij bolgewassen: Liliaceae. Lisse, Laboratorium voor Bloembollenonderzoek.

Felsenstein J., 1981. Evolutionary trees from DNA sequences: A maximum likelihood approach. Journal 
of Molecular Evolution 17: 368-376. DOI: 10.1007/ BF01734359.

Felsenstein J., 1985. Confidence limits on phylogenies: an approach using the bootstrap. Evolution 39: 783-791. DOI: 10.1111/j.1558-5646.1985.tb00420.x.

Hasegawa M., Kishino H., Yano T., 1985. Dating of the human-ape splitting by a molecular clock of mitochondrial DNA. Journal of Molecular Evolution 22: 160-174. DOI: 10.1007/BF02101694.

He Y., Gao F., Shen J., Liao F., Chen X., ... Chen S., 2019. A multiplex RT-PCR method for the simultaneous detection of Narcissus yellow stripe virus, Narcissus latent virus and Narcissus mosaic virus. Canadian Journal of Plant Pathology 41: 115-123. DOI: 10.1080/07060661.2018.1513074.

Jordan R., Hammond J., 1991. Comparison and differentiation of potyvirus isolates and identification of strain-, virus-, subgroup-specific and potyvirus group-common epitopes using monoclonal antibodies. Journal of General Virology 72: 25-36. DOI: 10.1099/0022-1317-72-1-25.

Kumar S., Stecher G., Li M., Knyaz C., Tamura K., 2018. MEGA X: Molecular Evolutionary Genetics Analysis across computing platforms. Molecular Biology and Evolution (F.U. Battistuzzi, ed.) 35: 1547-1549. DOI: 10.1093/molbev/msy096.

Larkin M.A., Blackshields G., Brown N.P., Chenna R., McGettigan P.A., ... Higgins D.G., 2007. ClustalW and ClustalX version 2.0. Bioinformatics 23: 29472948. DOI: 10.1093/bioinformatics/btm404.

Mowat W.P., Duncan G.H., Dawson S., 1988. Narcissus late season yellows potyvirus - symptoms, properties and serological detection. Annals of Applied Biology 113: 531-544. DOI: 10.1111/j.1744-7348.1988.tb03330.x.

Nemes K., Salánki K., 2020. A multiplex RT-PCR assay for the simultaneous detection of prevalent viruses infecting pepper (Capsicum annuum L.). Journal of Virological Methods 278: 113838. DOI: 10.1016/j.jviromet.2020.113838.

Pleše N., 1993. A presumable potyvirus infection of Sternbergia lutea (L.) Ker-G. (Amaryllidaceae). Acta Botanica Croatica 52: 5-7.

Salamon P., Palkovics L., 2005. Occurrence of Colombian datura virus in Brugmansia hybrids, Physalis peruviana L. and Solanum muricatum Ait. in Hungary. Acta Virologica 49: 117-122.

van Rijn J.F.A.T., Pfaff H.G.M., van Aartrijk J., van Nes C.R., Peters J.M.M., ... de Rooy M., 1995. Ziekten en afwijkingen bij bolgewassen: Amaryllidaceae, Araceae, Begoniaceae, Compositae, Iridaceae, Oxalidaceae, Ranunculaceae. Lisse, Laboratorium voor Bloembollenonderzoek, $190 \mathrm{pp}$.
White J.L., Kaper J.M., 1989. A simple method for detection of viral satellite RNAs in small plant tissue samples. Journal of Virological Methods 23: 83-93. DOI: 10.1016/0166-0934(89)90122-5. 